\title{
PATIENT CHARACTERISTICS AND RISK FACTORS FOR MORTALITY IN 504 HOSPITALIZED PATIENTS DUE TO COVID-19
}

\author{
COVID-19 NEDENIYLE HASTANEYE YATIRILMIŞ 504 HASTANIN ÖZELLIKLERI VE \\ MORTALITE AÇISINDAN RISK FAKTÖRLERI
}

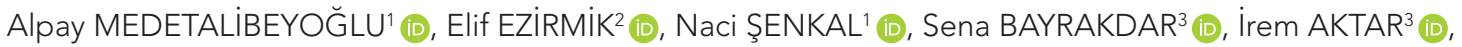 \\ Reyhan AKAS ${ }^{3}$ iD, Ebru YILMAZ (D), Huzeyfe ARICl ${ }^{1}$ (D) Murat KÖSE ${ }^{1}$ (D), Timur Selçuk AKPINAR ${ }^{1}$ (D), \\ Atahan ÇAĞATAY ${ }^{4}$ iD, Tufan TÜKEK ${ }^{1}$ (D) \\ ${ }^{1}$ Istanbul University, Istanbul Faculty of Medicine, Department of Internal Medicine, Istanbul, Turkey \\ ${ }^{2}$ Istanbul University, Istanbul Faculty of Medicine, Department of Public Health, Istanbul, Turkey \\ ${ }^{3}$ Istanbul University, Istanbul Faculty of Medicine, Bachelor of Medicine student, Istanbul, Turkey \\ ${ }^{4}$ Istanbul University, Istanbul Faculty of Medicine, Department of Infectious Diseases and Clinical Microbiology, Istanbul, Turkey
}

ORCID IDs of the authors: A.M. 0000-0002-5829-9186; E.E. 0000-0001-6828-4378; N.Ş. 0000-0001-7072-8724;

S.B. 0000-0002-4675-185X; I.A. 0000-0003-4279-0517; R.A. 0000-0002-2955-0685; E.Y. 0000-0002-5753-9790;

H.A. 0000-0003-4128-8533; M.K. 0000-0002-7487-9287; T.S.A. 0000-0002-9591-4475; A.Ç. 0000-0002-3051-8199; T.T. 0000-0002-4237-1163

Cite this article as: Medetalibeyoglu A, Ezirmik E, Senkal N, Bayrakdar S, Aktar I, Akas R, et al. Patient characteristics and risk factors for mortality in 504 patient characteristics and risk factors for mortality in 504 hospitalized patients due to COVID-19. J Ist Faculty Med 2022;85(1):1-8. doi: 10.26650/IUITFD.932128

\section{ABSTRACT}

Objective: In this study, we aimed to analyze the demographic characteristics, symptoms, and comorbidities of 504 patients hospitalized for COVID-19. We also sought to describe the relationship between these features and intensive care unit (ICU) admission and mortality.

Materials and Methods: This study is a descriptive study involving 504 COVID-19 patients hospitalized between 16.03.2020 and 07.05.2020 at Istanbul Universitys' Istanbul Faculty of Medicine Hospital. Information about the patients was obtained from the hospital automation system and evaluated retrospectively.

Results: The average age of the 504 patients was $56 \pm 15.14$, and $59.1 \%$ of them were male. The proportion of the patients admitted into ICU $11.9 \%$ and for $8.52 \%$ of them the disease resulted in death. Real time polymerase chain reaction (RT-PCR) test results were positive for $60.5 \%$ of the patients. The median time spent in the hospital was eight days. Fifty six percent of the patients had at least one accompanying comorbid disease, with hypertension (39.3\%) and diabetes (20.8\%) being the most common. Being 65 years old or older $(p<0.001)$, days spent in the hospital $(p<0.001)$, presence of at least one comorbidity $(p=0.009)$, hypertension ( $p=0.003)$, coronary artery disease $(p=0.004)$, congestive heart failure $(p=0.005)$ and dyspnea $(p<0.001)$ were all factors found in those admitted to ICU.

\section{ÖZET}

Amaç: Bu araştırmada, COVID-19 nedeniyle tedavi almak üzere hastaneye yatıılan 504 hastanın demografik özellikleri, semptomları ve komorbiditeleri incelenerek; bu özelliklerin yoğun bakım ünitesine yatış ve mortalite ile ilişkisini ortaya koymak amaçlanmıştır.

Gereç ve Yöntem: Bu araştırma, 16.03.2020-07.05.2020 tarihleri arasında COVID-19 tedavisi almak üzere İstanbul Üniversitesi İstanbul Tıp Fakültesi Hastanesi'ne yatırılan 504 hastanın dahil edildiği tanımlayıcı tipte bir araştırmadır. Hastalara ait bilgiler hastane otomasyon sisteminden alınarak retrospektif olarak değerlendirilmiştir.

Bulgular: Beşyüz dört hastanın yaş ortalaması 56ะ15,14 yıl, hastaların \%59,1'i erkekti. Yoğun bakım ünitesine yatışı olan hastaların oranı \%11,9; ölen hastaların oranı \%8,52 idi. Hastaların $\% 60,5$ 'inin test sonucu pozitifti. Hastanede kalınan sürenin ortancası sekiz gündü. Hastaların \%56'sının en az bir komorbid hastalığı vardı; hipertansiyon $(\% 39,3)$ ve diyabet $(\% 20,8)$ en sık eşlik eden komorbiditelerdi. Altmış beş yaş ve üzeri olmak $(p<0,001)$, hastanede kalınan gün sayısı $(p<0,001)$, en az bir komorbidite varlığı $(p=0,009)$, hipertansiyon $(p=0,003)$, koroner arter hastalığı $(p=0,004)$, konjestif kalp yetmezliği $(p=0,005)$ ve dispne $(p<0,001)$, yoğun bakıma yatış ile ilişkili bulunmuştur.

Corresponding author/iletişim kurulacak yazar: alibeyoglualpay@gmail.com

Submitted/Başvuru: 17.05.2021 • Revision Requested/Revizyon Talebi: 08.09.2021 •

Last Revision Received/Son Revizyon: 10.09.2021 • Accepted/Kabul: 17.09.2021 • Published Online/Online Yayın: 25.10 .2021 
Conclusion: COVID-19 infection leading to high morbidity-mortality rates and an increased requirement for ICU admission is mainly seen among older patients and those who have dyspnea. During the process of analyzing patients suspected of COVID-19 who are admitted to hospital, it is crucial to consider both the patient's age and any respiratory symptoms. Such a clinical evaluation is crucial for a better understanding of the course of the disease.

Keywords: COVID-19, mortality, admission to intensive care unit, COVID-19 risk factors
Sonuç: Yüksek morbidite-mortalite oranlarına ve yoğun bakım ünitesine yatış ihtiyacının artmasına neden COVID-19, özellikle yaşlı hastalarda ve dispnesi olan hastalarda daha yüksek mortalite oranlarına neden olmaktadır. Hastaneye başvuran COVID-19 şüpheli hastalar değerlendirilirken özellikle hastanın yaşı ve solunum sistemi semptomları göz önünde bulundurularak klinik değerlendirilmesinin yapılması hastalığın seyri açısından önem taşımaktadır.

Anahtar Kelimeler: COVID-19, mortalite, yoğun bakım ünitesine kabul, COVID-19 risk faktörü

\section{INTRODUCTION}

The World Health Organization (WHO) declared the severe acute respiratory syndrome coronavirus 2 (SARS-CoV-2) outbreak to be a pandemic on 11 March 2020 due to a continuous increase in the number of cases outside China (1). In Turkey, the first COVID-19 case was identified on the same date (2). The COVID-19 pandemic caused by the SARS-CoV-2 virus leads to high morbidity and mortality rates, long hospitalization, and increased necessity for ICU admissions. (3, 4). There were $138,411,980$ confirmed COVID-19 cases and 2,974,642 deaths worldwide as of 15 April 2021 (5). There were 4,086,957 confirmed COVID-19 cases and 35,031 deaths in Turkey up until the same date (6). COVID-19 fatality rate demonstrates variability depending on countries and regions and it ranges between 0-26.8\% (7-13).

The most common symptoms of COVID-19 infection are fever, cough, fatigue, malaise, shortness of breath, and myalgia $(7,8,14)$. Hypertension, diabetes, chronic heart disease, and chronic obstructive pulmonary disease (COPD) are the most common comorbidities accompanying COVID-19 $(7,15)$.

When the factors associated with COVID-19 mortality were analyzed, older age, male gender, hypertension, and the presence of diabetes were found to significantly correlate with mortality $(7,16)$. Pneumonia, kidney damage, shock status, heart failure, and acute respiratory distress syndrome (ARDS) constitute the main clinical factors affecting COVID-19 mortality. In most patients laboratory parameters associated with COVID-19 mortality were reported as follows: leukocytosis, neutrophilia, elevated levels of alanine aminotransferase (ALT), and aspartate aminotransferase (AST), creatinine, lactate dehydrogenase $(\mathrm{LDH})$, procalcitonin, C-reactive protein (CRP), $\mathrm{N}$-terminal pro-brain natriuretic peptide (NT-proBNP), ferritin, D-dimer, lymphopenia, thrombocytopenia, along with decreased levels of albumin $(7,8,17,18)$.

In this study, we aimed to analyze the demographic characteristics, symptoms, and comorbidities of 504 patients hospitalized for COVID-19. We also sought to describe the relationship between these features and intensive care unit (ICU) admission and mortality.

\section{MATERIALS AND METHODS}

The present descriptive study was approved by Istanbul Universitys' Istanbul Faculty of Medicine Clinical Research Ethics Committee, and written informed consent was waived (Date: 11.05.2020, No: 81246). We evaluated adult patients who were suspected of having COVID-19 and were hospitalized between 16.03.2020 and 07.05.2020. Patients who died or were discharged were removed from our study. We excluded patients who had missing data yet were still hospitalized. We collected the data according to age, gender, smoking habits, symptoms (fever, dry cough, dyspnea, fatigue, sputum, nausea, diarrhea, anosmia), contact history, PCR results, days spent in hospital, comorbid diseases (hypertension, diabetes, coronary artery disease, chronic obstructive pulmonary disease, congestive heart failure, malignancy) and patient outcome. We obtained the information from the hospital automation system. We investigated the effect of the baseline characteristics of the patients on ICU admission and death.

Continuous variables were presented as median (interquartile range) or mean \pm standard deviation, according to whether the distribution was normal or not. Categorical variables were presented as percentages. The compliance of the numerical values to the normal distribution was examined using histograms or analytic methods (Kolmogorov-Smirnov/Shapiro Wilk test). The student t-test, Mann-Whitney U test, Chi-square test, or Fisher's exact test (when chi-square test assumption does not hold due to low expected cell counts) were used to compare the differences between the groups. Univariable and multivariable logistic regression models were used to investigate the risk factors associated with in-hospital death. Considering the total number of deaths $(n=43)$ in our study and to avoid overfitting in the model, four variables were chosen for multivariable analysis based on previous findings and clinical constraints. Hosmer-Lemeshow goodness of fit statistics was used to assess model fit. An overall p-value of less than 0.05 was considered to show a statistically significant result. Statistical analyses were performed using the SPSS software v22 (IBM Inc, USA). 


\section{RESULTS}

We analyzed the data of 504 patients who remained in the study after excluding 93 of 597 patients hospitalized between 16.03.2020 and 07.05.2020. The mean age was $56 \pm 15.14$ years, ranging from 20 to 98 years, and most of the patients were male (59.1\%). Sixty patients $(11.9 \%)$ were admitted to ICU and 43 patients (8.5\%) died. The percentage of positive PCR results was $60.5 \%$. The median time from the onset of symptoms to hospitalization was five days (3-7). The median time spent in hospital was eight days (5-11). The most common symptoms were fatigue (91.1\%), dry cough (82.3\%) and fever (70.6\%), less common symptoms were dyspnea $(42.5 \%)$, nausea (16.7\%), diarrhea (12.1\%), anosmia (7.9\%) and sputum

Table 1: COVID-19 patients' (ICU patients and non-ICU patients) baseline demographic and clinical characteristics

\begin{tabular}{lc}
\hline Characteristics & $\mathrm{n}=504(\%)$ \\
Age, median (IOR) & $56(46-67)$ \\
Age $\geq 65$ years & $143(28.4 \%)$ \\
Gender & \\
Female & $206(40.9 \%)$ \\
Male & $298(59.1 \%)$ \\
RT-PCR positive & $305(60.5 \%)$ \\
Exposure history & $172(34.1 \%)$ \\
Smoker & $62(12.3 \%)$ \\
Symptoms & \\
Fever & $356(70.6 \%)$ \\
Cough & $415(82.3 \%)$ \\
Dispnea & $214(42.5 \%)$ \\
Fatigue & $459(91.1 \%)$ \\
Sputum & $15(3 \%)$ \\
Nausea & $84(16.7 \%)$ \\
Diarhea & $61(12.1 \%)$ \\
Anosmia & $40(7.9 \%)$ \\
Comorbidities & $282(56 \%)$ \\
Hypertension & $198(39.3 \%)$ \\
Diabetes & $105(20.8 \%)$ \\
COPD & $59(11.7 \%)$ \\
Coronary artery disease & $55(10.9 \%)$ \\
Congestive heart failure & $30(6 \%)$ \\
Malignancy & $43(8.5 \%)$ \\
\hline
\end{tabular}

ICU: Intensive care unit, IQR: Interquartile range, RT-PCR: Real time polymerase chain reaction, COPD: Chronic obstructive pulmonary disease
(3\%). The percentage of people with at least one comorbid disease was $56 \%$. Hypertension, the most common comorbid disease, was seen in 197 patients (39.3\%), followed by diabetes in 105 patients (20.8\%) (Table 1).

We found that older age ( $\geq 65$ years) was associated with ICU admission ( $p$ 0.001). In addition, days spent in hospital $(p<0.001)$, at least one comorbidity $(p=0.009)$, hypertension $(p=0.003)$, coronary artery disease $(p=0.004)$, congestive heart disease $(p=0.005)$, and dyspnea $(p<0.001)$ were found to be statistically significant (Table 2 ). We also found that older age ( $\geq 65$ years) $(p=0.001)$, days spent in hospital ( $p=0.001), I C U$ admission $(p<0.001)$, at least one comorbidity $(p=0.011)$, hypertension $(p=0.020)$, coronary artery disease $(p=0.017)$ and dyspnea $(p<0.001)$ were significantly associated with death. In contrast, the connection between patient mortality and fever $(p=0.026)$ and dry cough ( $p=0.024)$ was statistically less significant (Table 3).

In univariate analysis, the odds of in-hospital death were higher in patients with hypertension $(p=0.023)$ or coronary artery disease $(p=0.002)$. Age, days spent in hospital, ICU admission, and dyspnea were also associated with death. In multivariate analysis, older age and presence of dyspnea were associated with increased likelihood of death. There was no significant association between gender and ICU admission or mortality. Moreover, there was no significant association between PCR results and ICU admission or mortality (Table 4).

\section{DISCUSSION}

COVID-19 affects elderly patients more seriously by causing more severe clinical symptoms and higher mortality rates $(19,20)$. COVID-19 case-fatality rate increases rapidly with age. While the case fatality rate is $3.6 \%$ of cases in those aged between 60 and 69 , it rises to $8 \%$ in patients between 70 and 79 years and to $14.8 \%$ in cases aged 80 years or older (20). In the first case series reported from China, the proportion of the elderly patients among all patients was $15.1 \%$ (21). In Turkey, the proportion of patients aged 65 or older is $11 \%$. However, $73 \%$ of overall deaths were in this age group (22).

In this study, patients aged 65 or older form $67.4 \%$ of the deaths and $24.7 \%$ of the discharged patients $(p<0.001)$. In univariate analysis, being 65 years or older was found to be a factor that increases mortality risk by 6.3 times (95\% Cl 3.2-12.3; $p<0.001$ ). It was calculated that being 65 years or older increases the mortality risk by 4.94 times in multivariate analysis (95\% Cl 2.31-10.58; $\mathrm{p}<0.001)$. It has also been suggested in many previous studies that older age is an important risk factor for COVID-19 mortality (13, 23-29). Being 65 years or older has been stated as a risk factor for ICU admission and this outcome is in keeping with the literature $(4,29,30)$. 
Table 2: Baseline demographic and clinical characteristics of COVID-19 patients according to ICU admission rates

\begin{tabular}{|c|c|c|c|c|}
\hline Characteristics & $\begin{array}{c}\text { Total } \\
(n=504)\end{array}$ & $\underset{(n=444)}{\text { ICU - }}$ & $\begin{array}{l}\mathrm{ICU}+ \\
(n=60)\end{array}$ & $p$ value \\
\hline Age, mean (SD) & $56.41 \pm 15.14$ & $55.02 \pm 14.76$ & $66.71 \pm 13.94$ & $<0.001$ \\
\hline Age $\geq 65$ years & $143(28.4 \%)$ & $108(24.3 \%)$ & 35 (58.3\%) & $<0.001$ \\
\hline Gender (male) & $298(59.1 \%)$ & $257(57.9 \%)$ & $41(68.3 \%)$ & 0.122 \\
\hline RT-PCR positive & $305(60.5 \%)$ & $266(59.9 \%)$ & $39(65 \%)$ & 0.449 \\
\hline Exposure history & $172(34.1 \%)$ & $160(36 \%)$ & $12(20 \%)$ & 0.014 \\
\hline Smoker & 62 (12.3\%) & 57 (12.8\%) & $5(8.3 \%)$ & 0.319 \\
\hline $\begin{array}{l}\text { Days from symptom onset to } \\
\text { hospitalization, median (IQR) }\end{array}$ & $5(3-7)$ & $5(3-7)$ & $5(3-7)$ & 0.916 \\
\hline Days in hospital, median (IQR) & $8(5-11)$ & $7(5-10)$ & $14.5(9-21)$ & $<0.001$ \\
\hline Comorbidities & $282(56 \%)$ & $239(53.8 \%)$ & $43(71.7 \%)$ & 0.009 \\
\hline Hypertension & $198(39.3 \%)$ & $164(36.9 \%)$ & $34(56.7 \%)$ & 0.003 \\
\hline Diabetes & $105(20.8 \%)$ & $165(69.6 \%)$ & $13(21.7 \%)$ & 0.866 \\
\hline COPD & 59 (11.7\%) & 48 (10.8\%) & $11(18.3 \%)$ & 0.089 \\
\hline Coronary artery disease & 55 (10.9\%) & $42(9.5 \%)$ & $13(21.7 \%)$ & 0.004 \\
\hline Congestive heart failure & $30(6 \%)$ & $21(4.7 \%)$ & $9(15 \%)$ & 0.005 \\
\hline Malignancy & $43(8.5 \%)$ & $38(8.6 \%)$ & $5(8.3 \%)$ & 0.953 \\
\hline \multicolumn{5}{|l|}{ Symptoms } \\
\hline Fever & $356(70.6 \%)$ & $317(71.4 \%)$ & $39(65 \%)$ & 0.307 \\
\hline Dry cough & $415(82.3 \%)$ & $367(82.7 \%)$ & $48(80 \%)$ & 0.612 \\
\hline Dyspnea & $214(42.5 \%)$ & $165(37.2 \%)$ & 49 (81.7\%) & $<0.001$ \\
\hline Fatigue & 459 (91.1\%) & 405 (91.2\%) & $54(90 \%)$ & 0.756 \\
\hline Sputum & $15(3 \%)$ & $14(3.2 \%)$ & $1(1.7 \%)$ & 1 \\
\hline Nausea & $84(16.7 \%)$ & $78(17.6 \%)$ & $6(10 \%)$ & 0.140 \\
\hline Diarrhea & $61(12.1 \%)$ & 57 (12.8\%) & $4(6.7 \%)$ & 0.169 \\
\hline Anosmia & 40 (7.9\%) & $38(8.6 \%)$ & $2(3.3 \%)$ & 0.207 \\
\hline
\end{tabular}

ICU: Intensive care unit, SD: Standard deviation, IQR: Interquartile range, RT-PCR: Real time polymerase chain reaction, COPD: Chronic obstructive pulmonary disease

The overall percentage of patients who had at least one comorbidity (hypertension (39.3\%) and diabetes (20.8\%) being the most prevalent) was found to be $56 \%$. The results suggest that the presence of comorbidity strongly correlates with ICU admission and mortality ( $p=0.009$, $\mathrm{p}=0.011$ ). On ICU admission, hypertension, coronary artery disease and congestive heart failure $(p=0.003$, $\mathrm{p}=0.004, \mathrm{p}=0.005)$ and on mortality, hypertension and coronary artery disease $(p=0.020, p=0.017)$ were found to be gravely significant comorbidities. However, in multivariate analysis, there was no significant statistical correlation found between these comorbidities and mortality. Similarly, in the previous studies the most common comorbidities accompanying COVID-19 were found as follows: hypertension, diabetes, coronary artery disease $(26,31,32)$. The presence of multiple comorbidities was described as the most important risk factor for severe disease progression and mortality $(25,31,32)$. In a study conducted on patients aged 60 or older, the case fatality rate was found to be $1.4 \%$ in cases with no comorbidities. However, it was $13.2 \%$ in patients with cardiovascular disease, $9.2 \%$ in those with diabetes, $8.4 \%$ in those with hypertension, $8 \%$ in cases with chronic lung disease, and $7.6 \%$ in those with cancer (25). A greater severity of pneumonia, enzyme release related to tissue damage, inflammatory responses, and dysregulations of glucose metabolism were only observed in COVID-19 patients who had diabetes (33). According to multivariate analysis 
Table 3: Baseline demographic and clinical characteristics of the patients who were discharged and who died due to COVID-19

\begin{tabular}{|c|c|c|c|c|}
\hline Characteristics & $\begin{array}{c}\text { Total } \\
(n=504)\end{array}$ & $\begin{array}{l}\text { Discharged } \\
(n=461)\end{array}$ & $\begin{array}{l}\text { Died } \\
(n=43)\end{array}$ & $p$ value \\
\hline Age, mean (SD) & $56.41 \pm 15.14$ & $55.19 \pm 14.69$ & $69.53 \pm 13.69$ & $<0.001$ \\
\hline Age $\geq 65$ years & $143(28.4 \%)$ & $114(24.7 \%)$ & 29 (67.4\%) & $<0.001$ \\
\hline Gender (male) & $298(59.1 \%)$ & $270(58.6 \%)$ & $28(65.1 \%)$ & 0.404 \\
\hline RT-PCR positive & $305(60.5 \%)$ & $278(60.3 \%)$ & $27(62.8 \%)$ & 0.750 \\
\hline Exposure history & $172(34.1 \%)$ & $160(35.1 \%)$ & $10(23.3 \%)$ & 0.116 \\
\hline Smoker & $62(12.3 \%)$ & $56(12.1 \%)$ & $6(14 \%)$ & 0.730 \\
\hline $\begin{array}{l}\text { Days from symptom onset to } \\
\text { hospitalized, median (IQR) }\end{array}$ & $5(3-7)$ & $5(3-7)$ & $5(3-7)$ & 0.202 \\
\hline Days in hospital, median (IQR) & $8(5-11)$ & $7(5-10)$ & $12(7-17)$ & 0.001 \\
\hline ICU admission & 60 (11.9\%) & $24(5.2 \%)$ & $36(83.7 \%)$ & $<0.001$ \\
\hline Comorbidities & $282(56 \%)$ & $250(54.2 \%)$ & 32 (74.4\%) & 0.011 \\
\hline Hypertension & $198(39.3 \%)$ & $174(37.7 \%)$ & $24(55.8 \%)$ & 0.020 \\
\hline Diabetes & $105(20.8 \%)$ & 97 (21\%) & $8(18.6 \%)$ & 0.707 \\
\hline COPD & 59 (11.7\%) & $53(11.5 \%)$ & $6(14 \%)$ & 0.632 \\
\hline Coronary artery disease & 55 (10.9\%) & 45 (9.8\%) & $10(23.3 \%)$ & 0.017 \\
\hline Congestive heart failure & $30(6 \%)$ & 25 (5.4\%) & $5(11.6 \%)$ & 0.165 \\
\hline Malignancy & $43(8.5 \%)$ & $37(8 \%)$ & $6(14 \%)$ & 0.246 \\
\hline \multicolumn{5}{|l|}{ Symptoms } \\
\hline Fever & $356(70.6 \%)$ & 332 (72\%) & 24 (55.8\%) & 0.026 \\
\hline Dry cough & 415 (82.3\%) & $385(83.5 \%)$ & 30 (69.8\%) & 0.024 \\
\hline Dispnea & $214(42.5 \%)$ & $177(38.4 \%)$ & 37 (86\%) & $<0.001$ \\
\hline Fatigue & $459(91.1 \%)$ & 421 (91.3\%) & 38 (88.4\%) & 0.572 \\
\hline Sputum & $15(3 \%)$ & $15(3.3 \%)$ & 0 & 0.629 \\
\hline Nausea & $84(16.7 \%)$ & 78 (16.9\%) & $6(14 \%)$ & 0.618 \\
\hline Diarrhea & $61(12.1 \%)$ & 57 (12.4\%) & 4 (9.3\%) & 0.556 \\
\hline Anosmia & $40(7.9 \%)$ & $39(8.5 \%)$ & $1(2.3 \%)$ & 0.236 \\
\hline
\end{tabular}

ICU: Intensive care unit, SD: Standard deviation, IQR: Interquartile range, RT-PCR: Real time polymerase chain reaction, COPD: Chronic obstructive pulmonary disease

results from another study from Malesia, while diabetes in COVID-19 patients increased the risk of mortality by 12.2 , having hypertension increased mortality by 3.5 (34).

According to this study, there was no significant difference in terms of gender among the ICU and non-ICU patient groups $(p=0.122)$. There was also no significant difference between the deceasead and surviving patients groups in terms of gender $(p=0.404)$. However, this outcome shows consistency with other study results suggesting that gender is a risk factor for COVID-19 mortality and severe COVID-19 infection $(23,35,36)$. On the other hand, multiple studies reported that males are at great- er risk of severe disease progression and ICU admission due to COVID-19 infection (7, 29, 34, 37). Men carry an increased risk of severe COVID-19 infection by 1.73 times (95\% Cl 1.50-2.01) (37). The fact that the male gender was not found to be a significant risk factor was considered to be potentially related to the lack of homogeneity in gender distribution or an inadequate number of patients included in the study.

Our study concluded that smoking is not a notable risk factor for ICU admission due to COVID-19 and COVID-19 mortality $(p=0.319, p=0.730)$. There are complementary results with this outcome in other studies $(28,38,39)$. 
Table 4: Logistic regression analysis results associated with COVID-19 mortality

\begin{tabular}{|c|c|c|c|c|}
\hline & $\begin{array}{l}\text { Univariable OR } \\
(95 \% \mathrm{Cl})\end{array}$ & $p$ value & $\begin{array}{c}\text { Multivariable OR } \\
\qquad(95 \% \mathrm{Cl})\end{array}$ & $p$ value \\
\hline \multicolumn{5}{|c|}{ Demographics and characteristics } \\
\hline Age & $\begin{array}{c}1.068 \\
(1.044-1.093)\end{array}$ & $<0.001$ & & \\
\hline Age $\geq 65$ years & $\begin{array}{c}6.305 \\
(3.220-12.347)\end{array}$ & $<0.001$ & $\begin{array}{c}4.946 \\
(2.311-10.582)\end{array}$ & $<0.001$ \\
\hline Days in hospital & $\begin{array}{c}1.079 \\
(1.035-1.126)\end{array}$ & $<0.001$ & & \\
\hline ICU admission & $\begin{array}{c}93.642 \\
(37.772-232.158)\end{array}$ & $<0.001$ & & \\
\hline Comorbidities & $\begin{array}{c}2.455 \\
(1.208-4.990)\end{array}$ & 0.013 & & \\
\hline Hypertension & $\begin{array}{c}2.083 \\
(1.109-3.914)\end{array}$ & 0.023 & $\begin{array}{c}0.975 \\
(0.444-2.143)\end{array}$ & 0.950 \\
\hline Coronary artery disease & $\begin{array}{c}4.467 \\
(1.764-11.307)\end{array}$ & 0.002 & $\begin{array}{c}0.906 \\
(0.357-2.302)\end{array}$ & 0.836 \\
\hline Fever & $\begin{array}{c}0.491 \\
(0.260-0.926)\end{array}$ & 0.028 & & \\
\hline Cough & $\begin{array}{c}0.456 \\
(0.227-0.913)\end{array}$ & 0.027 & & \\
\hline Dyspnea & $\begin{array}{c}9.895 \\
(4.093-23.921)\end{array}$ & $<0.001$ & $\begin{array}{c}7.944 \\
(3.206-19.668)\end{array}$ & $<0.001$ \\
\hline
\end{tabular}

ICU: Intensive care unit, OR: Odds ratio, Cl: Confidence interval

In this study, the average number of days spent in hospital was eight. In terms of length of hospitalization a statistically significant difference was found between patients who were admitted into ICU and those who were not. Patients who were admitted into ICU had longer hospitalization times ( 7 days; 14.5 days, $p<0.001$ ). In univariate analysis, the number of days spent in hospital was found to correspond with mortality $(95 \% \mathrm{Cl} 1.035-1.126)$. Likewise, in other studies, it was reported that patients with severe COVID-19 infection spent more days in hospital $(p<0.001)(40)$. Among the patients admitted to hospital, the average number of days spent there were four days for patients treated on COVID-19 wards, eight days for patients treated in ICU but who did not need invasive mechanical ventilation (IMV), and 15 days for patients treated in ICU who needed IMV (41).

The presence of dyspnea was found to be a risk factor for both ICU admission due to COVID-19 and COVID-19 mortality $(p<0.001, p<0.001)$. According to the multivariate analysis results, dyspnea escalates the likelihood of multivariate mortality by 7.9 times $(95 \% \mathrm{Cl} 3.2-19.6$; $\mathrm{p}<0.001)$. Furthermore, as stated in another study, dyspnea raises the risk of mortality in multivariate patients by 4.52 times. (95\% Cl 3.15-6.48; $p<0.001)$ (42).
COVID-19 infection leading to high morbidity-mortality rates and an increased requirement for ICU admission also causes higher mortality rates among older patients and those with dyspnea. While analyzing patients suspected of having COVID-19 who are admitted to hospital, it is crucial for an understanding of the course of the disease to consider the patient's age and any respiratory symptoms during the clinical evaluation.

\section{The limitations of the study}

Several limitations of this study should be noted. First of all, it is a single-centered study with a limited number of patients. Secondly, baseline demographic and clinical features of the patients were obtained from the hospital automation system. Moreover, since the laboratory results of the patients were not included, it could not be evaluated whether these parameters are effective on ICU admission and mortality. Although all these factors constitute the limitations of this study, the fact that there was no lack of data, that the study included a considerable number of patients based on the dates given, and that certain risk factors associated with COVID-19 mortality were predicted are major strengths of this study. 
Ethics Committee Approval: This study was approved by the Clinical Research Ethical Committee of the Istanbul University, Istanbul Faculty of Medicine (Date: 11.05.2020, No: 81246).

Peer Review: Externally peer-reviewed.

Author Contributions: Conception/Design of Study- A.M., M.K.,T.T., A.Ç., T.S.A.; Data Acquisition- N.Ş., E.E., A.M., I.A., E.Y.; Data Analysis/Interpretation- S.B., R.A., N..S.., A.M., H.A.; Drafting Manuscript- E.E., R.A., I.A., S.B., E.Y., N.Ş., A.M., H.A.; Critical Revision of Manuscript- T.T., A.Ç., M.K., T.S.A., A.M.; Final Approval and Accountability- A.M., E.E., N.Ş., S.B., I.A., R.A., E.Y., H.A., M.K., T.S.A., A.Ç., T.T.

Conflict of Interest: Authors declared no conflict of interest.

\section{REFERENCES}

1. WHO Virtual press conference on COVID-19 - 11 March 2020 [Internet]. 2020 [cited 2021 Apr 16]. p. 1-17. Available from: https://www.who.int/docs/default-source/coronaviruse/ transcripts/who-audio-emergencies-coronavirus-pressconference-full-and-final-11 mar2020.pdf?sfvrsn=cb432bb3_2

2. Republic of Turkey Ministry of Health COVID-19 Information Platrform [Internet]. 2020. Available from: https://covid19. saglik.gov.tr/TR-66494/pandemi.html

3. Grasselli G, Pesenti A, Cecconi M. Critical care utilization for the COVID-19 outbreak in Lombardy, Italy early experience and forecast during an emergency response. J Am Med Assoc 2020;323(16):1545-6. [CrossRef]

4. Grasselli G, Zangrillo A, Zanella A, Antonelli M, Cabrini L, Castelli $A$, et al. Baseline characteristics and outcomes of 1591 patients infected with SARS-CoV-2 admitted to ICUs of the Lombardy region, Italy. JAMA - J Am Med Assoc 2020;323(16):1574-81. [CrossRef]

5. WHO Coronavirus (COVID-19) Dashboard |WHO Coronavirus (COVID-19) Dashboard With Vaccination Data. 2021 [cited 2021 Apr 16]. Available from: https://covid19.who.int/

6. Republic of Turkey ministry of health COVID-19 information platform general coronavirus table 2021. Available from: https://covid19.saglik.gov.tr/EN-69532/general-coronavirustable.html

7. Li J, Huang DQ, Zou B, Yang H, Hui WZ, Rui F, et al. Epidemiology of COVID-19: A systematic review and meta-analysis of clinical characteristics, risk factors, and outcomes. J Med Virol 2021;93(3):1449-58. [CrossRef]

8. Ge H, Wang X, Yuan X, Xiao G, Wang C, Deng T, et al. The epidemiology and clinical information about COVID-19. Eur J Clin Microbiol Infect Dis 2020;39(6):1011-9. [CrossRef]

9. Abdollahi E, Champredon D, Langley JM, Galvani AP, Moghadas SM. Temporal estimates of case-fatality rate for COVID-19 outbreaks in Canada and the United States. Can Med Assoc J 2020;192(25):E666-70. [CrossRef]

10. Yang S, Cao P, Du P, Wu Z, Zhuang Z, Yang L, et al. Early estimation of the case fatality rate of COVID-19 in mainland China: a data-driven analysis. Ann Transl Med 2020;8(4):128. [CrossRef]

11. Rajgor DD, Lee MH, Archuleta S, Bagdasarian N, Quek SC. The many estimates of the COVID-19 case fatality rate. Lancet Infect Dis 2020;20(7):776-7. [CrossRef]
12. Velavan TP, Meyer CG. The COVID-19 epidemic. Trop Med Int Heal 2020;25(3):278-80. [CrossRef]

13. Bertsimas D, Lukin G, Mingardi L, Nohadani O, Orfanoudaki A, Stellato B, et al. COVID-19 mortality risk assessment: An international multi-center study. PLoS One 2020;15(12):113. [CrossRef]

14. Yang J, Zheng Y, Gou X, Pu K, Chen Z. Prevalence of comorbidities and its effects in patients infected with SARSCoV-2: a systematic review and meta-analysis. Int J Infect Dis 2020;94:91-5. [CrossRef]

15. Emami A, Javanmardi F, Pirbonyeh N, Akbari A. Prevalence of underlying diseases in hospitalized patients with COVID-19: a systematic review and meta-analysis. Arch Acad Emerg Med 2020;8(1):e35. [CrossRef]

16. Gopal Rao G, Allen A, Papineni P, Wang L, Anderson C, McGregor A, et al. Cross-sectional observational study of epidemiology of COVID-19 and clinical outcomes of hospitalised patients in North West London during March and April 2020. BMJ Open 2021;11(2):1-9. [CrossRef]

17. Erol AT, Aşar S, Sabaz MS, Bilgin BÖ, Çukurova Z. Risk factors for 28-day mortality among COVID-19 patients in an intensive care unit of a tertiary care center in Istanbul. Med J Bakirkoy 2021;17(1):100-7. [CrossRef]

18. Jalali Nadoushan M, Ahmadi S, Jalali Nadoushan P, Azzi L, Carcano G, Gianfagna F, et al. Hematologic, biochemical and immune biomarker abnormalities associated with severe illness and mortality in coronavirus disease 2019 (COVID-19): a meta-analysis. Clin Chem Lab Med 2020;58(7):1021-8. [CrossRef]

19. Gómez-Belda AB, Fernández-Garcés M, Mateo-Sanchis E, Madrazo M, Carmona M, Piles-Roger L, et al. COVID-19 in older adults: What are the differences with younger patients? Geriatr Gerontol Int 2021;21(1):60-5. [CrossRef]

20. Wu Z, McGoogan JM. Characteristics of and important lessons from the coronavirus disease 2019 (COVID-19) outbreak in China: Summary of a report of 72314 cases from the Chinese center for disease control and prevention. JAMA - J Am Med Assoc 2020;323(13):1239-42. [CrossRef]

21. Guan W, Ni Z, Hu Y, Liang W, Ou C, He J, et al. Clinical characteristics of coronavirus disease 2019 in China. N Engl J Med 2020;382(18):1708-20. [CrossRef]

22. Republic of Turkey Ministry of Health COVID-19 Weekly Report [Internet]. 2020 [cited 2021 Apr 26]. Available from: https://covid19.saglik.gov.tr/Eklenti/39229/0/ covid-19-haftalik-durum-raporu---43pdf.pdf? tag1=70F7CD89B8F7191D8FAD3ACF29EF550190C31B61

23. Medetalibeyoglu A, Senkal N, Kose M, Catma Y, Bilge Caparali E, Erelel M, et al. Older adults hospitalized with COVID-19: Clinical characteristics and early outcomes from a single center in Istanbul, Turkey. J Nutr Heal Aging 2020;24(9):928-37. [CrossRef]

24. Weiss $P$, Murdoch DR. Clinical course and mortality risk of severe COVID-19. Lancet 2020;395:1014-5. [CrossRef]

25. Shahid Z, Kalayanamitra R, McClafferty B, Kepko D, Ramgobin D, Patel R, et al. COVID-19 and older adults: What we know. J Am Geriatr Soc 2020;68(5):926-9. [CrossRef]

26. Setiati S, Harimurti K, Safitri ED, Ranakusuma RW, Saldi SRF, Azwar MK, et al. Risk factors and laboratory test results associated with severe illness and mortality in COVID-19 patients: A systematic review. Acta Med Indones 2020;52(3):227-45. 
27. Van Halem K, Bruyndonckx R, Van Der Hilst J, Cox J, Driesen $\mathrm{P}$, Opsomer $\mathrm{M}$ et al. Risk factors for mortality in hospitalized patients with COVID-19 at the start of the pandemic in Belgium: a retrospective cohort study. BMC Infect Dis 2020;20:1-10. [CrossRef]

28. COVID-ICU Group on behalf of the REVA Network and the COVID-ICU Investigators. Clinical characteristics and day90 outcomes of 4244 critically ill adults with COVID-19: a prospective cohort study. Intensive Care Med 2021;47(1):6073. [CrossRef]

29. Grasselli G, Greco M, Zanella A, Albano G, Antonelli M, Bellani $G$, et al. Risk factors associated with mortality among patients with COVID-19 in intensive care units in Lombardy, Italy. JAMA Intern Med 2020;180(10):1345-55. [CrossRef]

30. Suleyman G, Fadel RA, Malette KM, Hammond C, Abdulla $H$, Entz $A$, et al. Clinical characteristics and morbidity associated with coronavirus disease 2019 in a series of patients in metropolitan Detroit. JAMA Netw Open 2020;3(6):1-12. [CrossRef]

31. Ejaz H, Alsrhani A, Zafar A, Javed H, Junaid K, Abdalla AE, et al. COVID-19 and comorbidities: Deleterious impact on infected patients. J Infect Public Health 2020;13(12):1833-9. [CrossRef]

32. Matta S, Chopra KK, Arora VK. Morbidity and mortality trends of Covid 19 in top 10 countries. Indian J Tuberc 2020;67:S167-72. [CrossRef]

33. Guo W, Li M, Dong Y, Zhou H, Zhang Z, Tian C, et al. Diabetes is a risk factor for the progression and prognosis of COVID-19. Diabetes Metab Res Rev 2020;36(7):e3319. [CrossRef]

34. Albitar O, Ballouze R, Ooi JP, Ghadzi SMS. Risk factors for mortality of COVID-19 patients. Diabetes Res Clin Pract. 2020;166:108923. [CrossRef]
35. Du RH, Liang LR, Yang CQ, Wang W, Cao TZ, Li M, et al. Predictors of mortality for patients with COVID-19 pneumonia caused by SARSCoV- 2: A prospective cohort study. Eur Respir J 2020;55(5):1-8.

36. Van Halem K, Bruyndonckx R, Van Der Hilst J, Cox J, Driesen $\mathrm{P}$, Opsomer $\mathrm{M}$ et al. Risk factors for mortality in hospitalized patients with COVID-19 at the start of the pandemic in Belgium: a retrospective cohort study. BMC Infect Dis 2020;20(1):1-10. [CrossRef]

37. Matsushita K, Ding N, Kou M, Hu X, Chen M, Gao Y, et al. The relationship of COVID-19 severity with cardiovascular disease and its traditional risk factors: A systematic review and meta-analysis. Glob Heart 2020;15(1):1-14. [CrossRef]

38. Zheng Y, Xiong C, Liu Y, Qian X, Tang Y, Liu L. Epidemiological and clinical characteristics analysis of COVID-19 in the surrounding areas of Wuhan, Hubei Province in 2020. Pharmacol Res 2020;157:1-6. [CrossRef]

39. Castelnuvo A, Bonaccio M, Costanzo S, Gialluisi A. Common cardiovascular risk factors and in-hospital mortality in 3,894 patients with COVID-19: survival analysis and machine learning-based findings from the multicentre Italian CORIST Study. Nutr Metab Cardiovasc Dis 2020;30(11):1899-913. [CrossRef]

40. Huang $H$, Song $B, X u Z$, Jiao $Y$, Huang $L$, Zhao $P$, et al. Predictors of coronavirus disease 2019 severity: A retrospective study of 64 cases. Jpn J Infect Dis 2021;74(1):54-60. [CrossRef]

41. Di Fusco M, Shea KM, Lin J, Nguyen JL, Angulo FJ, Benigno $\mathrm{M}$, et al. Health outcomes and economic burden of hospitalized COVID-19 patients in the United States. J Med Econ 2021;24(1):308-17. [CrossRef]

42. Yang L, Jin J, Luo W, Gan Y, Chen B, Li W. Risk factors for predicting mortality of COVID-19 patients: A systematic review and meta-analysis. PLOS One 2020;15(11):1-11. [CrossRef] 